\title{
MAKNA DAN FUNGSI KAIN ULOS PADA PUSAT LATIHAN OPERA BATAK PEMATANG SIANTAR (PLOt) DI PEMATANG SIANTAR PROVINSI SUMATERA UTARA
}

\author{
Enrico Alamo ${ }^{1 *}$, Meria Eliza $^{2 *}$, Giat Syailillah ${ }^{3 *}$ \\ Program Studi Teater dan Program Studi Televisi dan Film \\ Fakultas Seni Pertunjukan dan Fakultas Seni Rupa dan Desain \\ Institut Seni Indonesia Padangpanjang \\ Jl. Bahder Johan, Guguak Malintang, Padangpanjang, Kota Padangpanjang, Kode Pos 27126 \\ Sumatera Barat. Indonesia \\ Email: godottwo@gmail.com,meriaeliza@gmail.com, giatsyailillah07@gmail.com
}

\begin{abstract}
Abstrak
Ulos merupakan pakaian tradisi yang dapat kita lihat dalam berbagai acara adat Batak seperti; lahiran, pernikahan, kematian dan upacara-upacara adat Batak lainnya di sub Batak; Mandailing, Pakpak, Dairi, Sipirok-Angkola dan Karo. Selain sebagai kain khas di masyarakat Batak, Ulos diyakini dapat menimbulkan rasa hangat dan menaikkan tondi (raga) karena unsur 'sakral' yang melekat didalam Ulos. Pada masa lalu kain Ulos ditenun oleh penenun 'spritual' dengan menggunakan pewarna alami. Kain Ulos juga merupakan kain penanda daerah; tingkatan sosial dan marga (nama keluarga). Maka tidak sembarang kain Ulos dapat diberikan kepada seseorang ataupun komunitas. Pusat Latihan Opera Batak (PLOt) Pematang Siantar. Sumatera Utara salah satu komunitas pengguna kain Ulos dalam setiap kegiatannya. Group Opera Batak ini sampai sekarang masih bertahan dan eksis dalam berbagai pertunjukan. Pentas-pentasnya merambah banyak negara. Lakon-lakon yang dimainkan berkisah tentang kehidupan masyarakat Batak dan epos kepahlawanan Batak. Misi group ini menjaga warisan budaya dan mengembangkan seni tradisi. Untuk itu, setiap pemanggungannya PLOt setia dalam menggunakan kain Ulos hasil tenunan tangan. Dilihat dari corak, warna dan motif kain-kain Ulos yang digunakan PLOt terkesan 'mewah' karena nilai artistik didalamnya. Hal ini, tentunya tidak sembarang modifikasi yang dilakukan oleh PLOt karena fungsi dan makna kain Ulos secara budaya memiliki arti yang sarat dengan ketentuan adat. Dalam hal tersebut, kami mencoba meneliti fungsi dan makna kain Ulos pada group Pusat Latihan Opera Batak yang berdomisili di Pematang Siantar. Sumatera Utara. Penelitian ini juga sebagai bagian dari tugas Pusat Kajian Pakaian Tradisi yang tidak saja meneliti corak dan motif tapi lebih jauh penggunaan kain Ulos diluar acara adat dan upacara-upacara adat.
\end{abstract}

Kata Kunci: ulos, adat, makna, fungsi, PLOt.

\begin{abstract}
Ulos is a traditional Batak clothing that we can find in traditional events; birth, marriage, death and other Batak traditional ceremonies such as: Mandailing, Pakpak, Dairi, Sipirok-Angkola and Karo. Apart from being a typical cloth in the Batak community, Ulos is believed to be able to create a feeling of warmth and raise tondi (raga) because of the 'sacred' element inherent in Ulos. In the past, Ulos cloth was woven by 'spiritual' weavers using natural dyes. Ulos cloth is also a regional marker cloth; social level, and clan (surname). So not just any Ulos cloth can be given to someone or the community. Batak Opera Training Center (PLOt) Pematang Siantar. North Sumatra is one of the Ulos cloth user communities in every activity. The Batak Opera Group has undoubtedly existed until now. His performances reached many countries. The plays that are played also tell about the life of the Batak people and the epics of Batak heroism. The group's mission is to protect cultural heritage and develop traditional arts. For this reason, every stage of the PLOt is faithful in using hand-woven Ulos cloth. Judging from the patterns, colors and motifs of the Ulos fabrics used by PLOt, they seem "luxurious" because of their artistic value. This, of course, is not just any modification made by PLOt because the function and meaning of Ulos cloth is culturally meaningful with customary provisions. In this regard, we tried to examine the function and meaning of the Ulos cloth in the Batak Opera Training Center group which is domiciled in Pematang Siantar. North Sumatra. This research is also part of the task of the Center for Traditional Clothing Studies, which is not only examining patterns and motifs but furthermore the use of Ulos cloth outside of traditional events and traditional ceremonies.
\end{abstract}

Keywords: ulos, custom, meaning, function, PLOt. 


\section{PENDAHULUAN}

Batak merupakan suku terbesar di provinsi Sumatera Utara, terdiri enam bagian suku didalamnya. Sitor Situmorang menjelaskan dalam bukunya Toba $\mathrm{Na}$ Sae yaitu, Batak Toba, Mandailing, Simalungun, Karo, Pakpak dan Angkola (Situmorang, 2004). Suku yang sebagian besar mendiami kawasan Bukit barisan ini memiliki pakaian tradisional yang disebut Ulos. Namun demikian, Ulos sangat jarang digunakan untuk kegiatan sehari-hari karena dianggap sakral. Ulos memiliki filosofi tersendiri bagi komunitas pemakainya. Setiap Ulos mempunyai makna tersendiri atau secara sederhana Ulos mempunyai sifat, keadaan, fungsi dan hubungan dengan hal atau benda tertentu sehingga Ulos tidak dapat dipisahkan dari kehidupan orang Batak Toba (Niessen, 1985). Ketika seseorang ingin memberikan Ulos (mangUlosi) kepada orang lain, ada aturan-aturan yang harus dipatuhi. Aturan tersebut adalah orang hanya boleh memberikan Ulos (mangUlosi) kepada mereka yang menurut ikatan kekerabatannya lebih rendah dari pihak pemberi Ulos. Sebagai contohnya, orangtua boleh mangUlosi anaknya tetapi anak tidak boleh mangUlosi orangtua.

Demikian juga, hanya pihak hula-hula yang dapat mangUlosi bere dan tidak boleh sebaliknya (Niessen, 1985). Hal ini juga dinyatakan oleh Sitor Situmorang, Sebagai contoh, di kalangan orang Batak Toba sering terdengar istilah mangUlosi. Dalam pengertian adat Batak mangUlosi (memberikan ulos) tidak hanya melambangkan pemberian kehangatan namun juga melambangkan kasih sayang dan berkat melalui doa (umpasa) kepada penerima ulos (Simorangkir, 2006).

Kain Ulos dibuat secara manual (tenunan tangan) dengan waktu pengerjaan berbulan-bulan. Bahkan bisa hitungan tahun untuk satu kain Ulos. Selain pembuatan yang lama, tidak semua orang bisa menenun Ulos. Pada umumnya dalam Ulos terdapat tiga panel besar, panel kiri dan kanan serta panel di tengah yang menyajikan motif-motif dekoratif. Ketiga panel ini saling menunjang satu sama lain seperti konstruksi kehidupan bangunan rumah orang Batak. Selain pada pola panel, pola pewarnaan pada Ulos juga memiliki makna yang terkandung di dalamnya (Hasibuan, 1985). Pewarnaan seluruh jenis Ulos menggunakan tiga warna utama yaitu putih, merah dan hitam. Putih (bontar) melambangkan benua atas (banua ginjang) atau simbol dari singgasana Mulajadi na Bolon sebagai lambang kehidupan. Di sisi lain, warna hitam melambangkan benua bawah (bапиa toru) sedangkan warna merah melambangkan benua tengah (banua tonga) (Situmorang, 2004).

Kain Ulos bukan sekedar kain tenunan tangan, dibalik warna dan motif yang tercipta sarat dengan makna dan filosofis kehidupan. Dimasa lalu kain Ulos hanya dikerjakan oleh penenun 'spritual', proses pengerjaannya (menenun) melihat hari dan waktu yang menentukannya penenun itu sendiri sesuai dengan keyakinan yag dimilikinya. Hal tersebut turut melatari penggunaannya. Tidak sembarang waktu dipakaikan, sebagaimana pakaian sehari-hari. Sebagian marga percaya Ulos dianggap sebagai 'jimat' diyakini memilikii satu kekuatan yang mampu melindungi tondi (raga) dari roh jahat. Oleh karena itu, kain Ulos bisa dianggap sebagai sesuatu yang diberkati dengan kekuatan keramat (Vergouwen, 1986).

Secara histori, keberadan Ulos berfungsi untuk menghangatkan badan, namun seurut perkembangan zaman, kain Ulos menambahkan fungsi simbolik yang erat hubungannya dengan berbagai aspek kehidupan masyarakat Batak. Dalam buku Orientasi Nilai-Nilai Budaya Batak, Basyral menjelaskan: Menurut pemikiran leluhur Batak Toba, Ulos merupakan salah satu bagian dari tiga unsur sumber kehangatan. Ketiga sumber kehangatan itu yaitu matahari, api, dan Ulos. Dari ketiga sumber kehangatan tersebut Ulos dianggap yang paling nyaman dan akrab dengan kehidupan sehari-hari. Hal ini disebabkan oleh matahari sebagai sumber utama kehangatan tidak bisa diperoleh pada malam hari, sedangkan api dapat menjadi bencana jika lalai menggunakannya (Harahap, 1987).

Ada bebarapa tahapan pemberian Ulos, Pada saat dilaksanakannya upacara kelahiran, pihak hula-hula hanya menyediakan dua buah Ulos yaitu Ulos parompa (menggendong) untuk anak dan Ulos pargomgom mampe goar untuk orang tua laki-laki. Dalam hal ini, jenis Ulos yang diberikan kepada anak sebagai parompa berupa Ulos mangiring atau Ulos bintang maratur sedangkan untuk orang tua laki-laki dapat diberikan Ulos suri-suri ganjang atau Ulos sitoluntuho. Selain itu, pihak hula-hula juga harus Ulos bulang-bulang untuk ompung/kakek dan neneknya (Vergouwen, 2004).

Kemudian peristiwa perkawinan, ada dua suhut, yaitu suhut dari pihak hula-hula dan suhut dari pihak boru. Bagi upacara perkawinan adat Batak Toba, baik orangtua pengantin perempuan maupun orangtua pengantin laki- laki merupakan suhut. Hal ini disebabkan oleh masing-masing pihak mengundang 


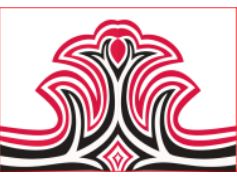

para kerabatnya untuk menghadiri upacara perkawinan adat tertentu. Para undangan itu disebut undangan paranak (penerima perempuan) dan undangan parboru (pemberi perempuan). Selama prosesi adat perkawinan, kedua pihak mempelai dan masing- masing keluarga inti dari mempelai akan menerima pemberian (tumpak) dari undangan/tamu yang datang. Pemberian (tumpak) tersebut dapat berupa Ulos, dekke, uang dan beras. Bagi masyarakat Batak Toba, jenis pemberian baik uang ataupun beras mengandung makna simbolik. Mereka yang memberikan uang bermakna bahwa mereka terlibat di dalam "pembelian” perempuan itu. Dalam hal ini, mereka membantu pihak laki-laki untuk memberikan boli (pembayaran perkawinan) ke pihak perempuan. Sementara bagi yang memberikan beras, dekke (ikan) dan Ulos bermakna bahwa mereka pun mendapat hak yang sama untuk menerima boli berbentuk uang dari pihak perempuan yang menikahkan anak perempuannya (Vergouwen, 2004). Selanjutnya saat kemalangan duka cita dan kematian. Pemberian Ulos pada upacara kematian pada umumnya melambangkan hubungan yang erat antara si penerima dan si pemberi Ulos. Ulos yang diberikan sebagai tanda dukacita disebut Ulos Tujung, yang artinya Ulos tanda berkabung. Saat penyerahan Ulos, didahului dengan kata-kata sambutan baik dari keluarga yang meninggal, dari hula-hula. Satu atau dua hari sebelum jenazah dikubur, pihak hula-hula menyerahkan pula Ulos yang khusus untuk jenazah. Penyerahan Ulos ini dimaksudkan agar jenazah selamat dalam perjalanannya dan mendapat lindungan dari Yang Maha Kuasa. Ulos yang diserahkan kepada jenazah disebut dengan "Ulos Saput".

Tiga hal dalam kehidupan yang diyakini masyarakat Batak adalah: darah (mudar), nafas (hosa) dan kehangatan. Kehangatan ada pada matahari, api dan Ulos. Ulos dianggap lebih praktis digunakan dibandingkan matahari maupun api. Namun demikian, Ulos tidak dibenarkan dipakai sembarangan karena telah dituangkan dalam aturan adat yang berbunyi antara lain: Ulos hanya diberikan kepada kerabat yang di bawah kita, misalnya, natoras tu ianakhon (orang tua kepada anak), hula-hula kepada boru. Penggunaannya pun dibagi sesuai jenisnya, untuk Siabithonon (dipakai ke tubuh menjadi baju atau sarung) digunakan Ulos Ragidup, Sibolang, Runjat, dan Jobit. Sedangkan Sihadanghononhon (diletakan di bahu) digunakan Ulos Sirara, Sumbat, Bolean dan Mangiring. Selanjutnya Sitalitalihononhon (pengikat kepala) digunakan Ulos Tumtuman, Mangiring dan Padang Rusa.
Gorga : Jurnal Seni Rupa

Volume 10 Nomor 01 Januari-Juni 2021

p-ISSN: 2301-5942 | e-ISSN: 2580-2380

Ulos dapat dibedakan sesuai nama dan fungsinya, berikut beberapa nama Ulos dan fungsinya: 1. Jugia, Ulos ini agak sulit ditemukan karena sudah jarang digunakan selain itu teknik pembuatan Ulos ini dalam kategori Sipitu lili/7 lidi. Pada masa lalu digunakan khusus oleh tetua yang sangat terhormat karena keberhasilan mencapai kekayaan, keturunan, dan wibawa serta tanpa cacat sosial. Pada perkembangannya penggunaan Ulos ini tidak begitu jelas digunakan untuk bagian tubuh mana; misalnya untuk selempang dibahu atau dililitkan ke bagian pinggang sampai ke atas tumit. 2 Napinussaan, Ulos antara jugia dan ragidup, dengan motif-motif khusus atau sesuai dengan pesanan kepada penenun. Karena motif-motif khusus itu jenis napinunsaan maksudnya kategorial karena ada beberapa nama Ulos termasuk dalam kategori ini. Misalnya ragi pakko, sitolu tuho, dll. Penggunaan Ulos ini juga sangat tertentu atau tidak semua orang bisa menggunakan. Jenis-jenis tertentu seperti ragi pakko digunakan sebagai penutup bagian pinggang lelaki.

Sedangkan sitolu tuho untuk penutup badan wanita. 3 Ragidup, Ulos ini dapat diartikan sebagai ragi hidup dan termasuk dalam teknik silima lili/5 lidi. Digunakan oleh orang tua (laki-laki dan perempuan) berdasarkan statusnya berketurunan sudah sampai memiliki cucu dan cicit. Ini merupakan Ulos dalam upacara adat. 4 Ragihotang, Ulos ini digunakan oleh pria yang sudah menikah dan secara umum diperolehnya sewaktu adat pernikahan. Pada masa dulu dipakai dikerja lapangan tradisional (termasuk perang) yang bisa digunakan sebagai selempang. 5 Mangiring, Ulos ini sering difungsikan sebagai ikat/penutup kepala pria (dalam adat dan situasi perang) serta menjadi kain gendongan bayi oleh ayah atau ibunya. 6. Bintang Maratur, Ulos ini difungsikan oleh ibu-ibu dan wanita yang belum menikah sebagai penutup kepala sewaktu bekerja. Penggunaan Ulos ini masuk dalam kategori Ulos sehari-hari, termasuk untuk penutup badan dengan Ulos yang berfungsi sebagai penutup tubuh perempuan sampai sebatas dada abit ginjang (kain panjang). 7 . Surisuri motif Ulos ini terkesan seperti sisir dengan garis-garis yang teratur. Digunakan secara umum oleh tetua sebagai selempang. Di daerah Simalungun jenis Ulos surisuri juga digunakan oleh perempuan saja. 8 . Bolean, Ulos ini motifnya sama seperti Ulos surisuri dengan tambahan variasi garis, warna cenderung indigo. Banyak pendapat yang mengatakan pada masa dulu sering digunakan oleh Sisingamangaraja XII sebagai selempang. 9. Sibolang, Ulos ini pada masa lalu sering dipakai untuk kegiatan sehari-hari, kemudian direduksi maknanya di zaman modern sebagai Ulos mistis dan berbau duka, warna Ulos ini kebanyakan 
indigo. Digunakan di luar dan di dalam rumah tanpa terikat dengan adat atau upacara. Jenis Ulos sibolang ada juga dengan warna putih dan disebut sibolang pamontari (biasa dipakai waktu suasana suka cita). 10. Sadum, Ulos ini terlihat feminim pada awalnya dibuat sebagai tiruan dan pengembangan Ulos sadum Angkola kemudian dikembangkan di Tarutung pada tahun 1930an. Ulos ini secara produksi sangat menjanjikan, apalagi wilayah Angkola dan Silindung sebagai pemasok Ulos terbesar di Sumatera Utara sangat berdekatan yang menguntungkan bagi perajin Ulos.

Jenis-jenis Ulos lainnya secara fungsional masih memerlukan penelitian secara intensif karena secara tenunan tangan dikerjakan oleh petenun sebagai seniman spiritual. Sebagian besar Ulos telah punah karena tidak diproduksi lagi, seperti Ulos Raja, Ulos Ragi Botik, Ulos Gobar, Ulos Saput (Ulos yang digunakan sebagai pembungkus jenazah), dan Ulos Sibolang.

Pusat Latihan Opera Batak yang disingkat PLOt berada di Pematang Siantar, provinsi Sumatera Utara. Group opera Batak ini sejak lama eksis membawakan lakon atau kisah-kisah opera Batak seperti, Boru Tumbaga, Sijonaha, Perempuan Di Pinggir Danau hingga sekarang. Keberadaan group ini sudah tidak asing lagi di Sumatera Utara bahkan Indonesia. Karena rutinitas pentasnya, hampir tiap tahun bisa empat sampai lima kali pementasan. Bahkan pentas-pentas group ini merambah ke berbagai negara menampilkan pertunjukan Opera Batak. Selain melestarikan seni tradisi dengan melakukan pementasan, grup ini turut andil dalam menjaga warisan budaya suku Batak. Hal ini tercermin pada pentas-pentas operanya yang selalu menggunakan kain Ulos. Kain Ulos yang digunakan pun hasil tenunan tangan. Berbeda dengan group opera Batak lainnya yang masih mencampurkan kostumkostum pertunjukannya antara kain Ulos buatan tangan dan kain Ulos hasil olahan mesin tenun. Jika dilihat, hal praktis lebih efektif jika memakai Ulos olahan mesin. Namun hal ini ditabukan oleh group opera Batak yang memasuki usia 15 tahun ini.

Kain Ulos olahan tangan dan Ulos produk mesin, sepintas terlihat sama dari harga jauh lebih murah dan jumlah produksi jauh lebih banyak. Namun hal ini tidak membuat paropera di Pusat Latihan Opera Batak berubah pikiran untuk menggunakan kain Ulos olahan mesin. Kesetiaan grup opera Batak ini pada Ulos tenunan tangan salahsatu hal yang menarik untuk diteliti. Biaya produksi, terutama untuk kostumkostum; panortor, pemain dan pemusik tentunya
Gorga : Jurnal Seni Rupa

Volume 10 Nomor 01 Januari-Juni 2021

p-ISSN: 2301-5942 | e-ISSN: 2580-2380

menjadi sangat mahal. Setiap pendukung sedikitnya 2 hingga sampai 5 helai kain Ulos yang dibutuhkan.

Penataan kain Ulos pada pertunjukan opera Batak terdapat perbedaan dengan pemakaian kain Ulos dalam acara adat maupun upacara-upacara adat Batak, Namun perbedaan ini sepertinya dapat dipertimbangkan. Penggunaan kain Ulos pada opera Batak lebih sering menggabungkan kain-kain Ulos yang berlainan motif dan nama pada kostum-kostum pertunjukannya. Tentunya hal ini telah melalui pertimbangan, tidak sembarangan orang yang bisa memodifikasi apalagi kain Ulos sarat dengan filosofi dan makna belum lagi sarat dan ketentuan adat didalamnya. Hal ini juga menjadi pedoman pada setiap pertunjukan opera Batak. Pertunjukan opera Batak dengan judul: Ugamo Malim Horja Bolon Naparpudi. "Kostum pertunjukan opera Batak seluruhnya menggunakan ulos yang dipilih berdasarkan makna dan fungsinya. Pemilihan ulos tidak sembarang dilakukan agar tidak salah persepsi" (Alamo, 2020: 59 -71).

Sampai saat ini Pusat Latihan Opera Batak belum pernah mendapat kritikan, ancaman atau amaran dari apa yang mereka lakukan, bahkan sebaliknya kostumkostum pertunjukan yang mereka gunakan dengan media Ulos dari berbagai jenis, motif dan warna menjadi terlihat "mewah". Untuk itu peneliti, dalam hal tersebut mencoba meneliti sebagai bagian Kajian Pakaian Tradisi yang tidak saja meneliti corak dan motif tapi lebih jauh penggunaan kain Ulos pada pertunjukan Opera Batak.

PLOt Pematang Siantar didirikan pada tahun 2005 oleh Lena Simanjuntak-Mertes, Sitor Situmorang, Barbara Brouwer, dan Tompson Parningotan Hutasoit. Group Opera Batak ini bisa dikatakan merupakan lanjutan dari program revitalisasi yang mengahasilkan satu grup percontohan Opera Batak yakni Grup Opera Silindung (GOS) melalui Asosiasi Tradis Lisan (ATL) pada tahun 2002. Program ATL pada saat itu adalah menghidupkan kembali kesenian-kesenian yang mulai punah (revitalisasi) terutama di pulau Sumatera. Melalui program ini muncul grup percontohan yakni, Grup Opera Silindung (GOS). Grup Opera Silindung sempat beberapa kali melakukan pementasan di Pematang Siantar, Medan, Jakarta, Sipoholon, Laguboti dan Tarutung. Program revitalisasi yang diadakan oleh ATL juga menghasilkan kebaruan pada Opera Batak, terutama dalam struktur pertunjukan Opera Batak. Pementasan Opera Batak yang semula berdasarkan ide dan alur cerita berubah dimulai dengan menggunakan naskah sebagaimana pertunjukan teater modern. Pemanggungan yang semula tidak 
diperhitungkan unsur artistiknya kini menjadi prioritas. Hal ini sedikit berbeda dengan pentas-pentas Opera Batak yang dibawakan oleh Tilhang Oberlin Gultom pada masa setelah kemerdekaan. Sebelumnya Sitor Situmorang pada tahun 1981 melalui AWK Samosir sempat memainkan Opera Batak yang berjudul "Pulo Batu" dengan sutradara Wahyu Sihombing. PLOt dalam perjalanannya memainkan beberapa naskah yang ditulis oleh Thompson Hutasoit dan Lena Simanjuntak yakni; Boru Tumbaga dan Perempuan Di Pinggir Danau.

Penelitian merupakan rangkaian kegiatan ilmiah dalam rangka pemecahan suatu permasalahan. Penelitian bertujuan mencarikan penjelasan dan jawaban terhadap permasalahan serta memberikan alternatif yang dapat digunakan untuk pemecahan masalah. Ingin menganalisis keberadaan PLOt di Pematang Siantar, Sumatera Utara. Mendeskripsikan penggunaan Ulos dan unsur-unsur lainnya bagi pertunjukan Opera Batak.

Opera Batak tidak mengenal bentuk naskah lakon yang baku seperti bentuk teater modern yang mensyaratkan kelengkapan suatu bentuk teater, namun hanya berupa instruksi atau suatu improvisasi yang diberikan kepada pemain yang diselingi oleh pola-pola awalan untuk membentuk struktur dramatik.

Bentuk pertunjukan yang disajikan dalam opera Batak, bila merujuk pada pemikiran Jakob Soemardjo dapat dikategorikan sebagai bentuk teater rakyat. Seperti yang dijelaskan sebagai berikut: Unsur-unsur teater rakyat yang pokok adalah cerita, pelaku dan penonton. Unsur cerita dapat diperpanjang atau diperpendek menurut respon dan suasana penontonnya. Cerita dibawakan dengan akting (pemeranan) atau dengan menari dan menyanyi. Para pelaku berkostum sesuai dengan referensi budaya masyarakatnya, meskipun ada acuan terhadap tradisi lama. Ciri-ciri umum teater rakyat ini adalah : (1) Cerita tanpa naskah dan digarap berdasarkan peristiwa sejarah, dongeng, mitologi atau kehidupan sehari-hari; (2) Penyajian dengan dialog, tarian dan nyanyian; (3) Unsur lawakan selalu muncul; (4) Nilai dan laku dramatik dilakukan secara spontan, serta dalam satu adegan terdapat dua unsur emosi sekaligus, yakni tertawa dan menangis; (5) Pertunjukan menggunakan tetabuhan atau musik tradisional; (6) Penonton mengikuti pertunjukan secara santai dan akrab dan bahkan tak terelakkan adanya dialog langsung antara pelaku dan publiknya; (7) Mempergunakan bahasa daerah; dan (8) Tempat pertunjukan terbuka dalam bentuk arena (dikelilingi penonton). (Soemardjo, 1997:18-19).
Ketertarikan peneliti terhadap PLOt dalam penelitian ini, pertama; PLOt merupakan teater rakyat yang memiliki kekhasan. Pertama, bentuk pertunjukannya, selain menggunakan naskah bisa juga tidak, hanya alur cerita yang disepakati, kedua; penggunaan kain Ulos tenunan tangan dalam setiap pertunjukannya yang dimana tidak kita temukan dalam group opera Batak lainnya. Motif, corak warna Ulos yang digunakan terlihat mewah dan elegan mengandung daya magis dalam seni pertunjukan ini yang biasanya ditemukan pada acara-acara adat masyarakat batak. Penulis berasumsi bahwa penggunaan kain Ulos sebagai kostum pertunjukan tidak sembarang pilih bahkan memiliki penenun tetap sebagai bagian kesejarahan group opera batak ini. Hal inilah perlu diteliti dan dilacak lebih jauh sebagai topik penelitian yang menarik untuk dilakukan sebagai bentuk penelitian.

Kebaruan penelitian ini terletak pada upaya menemukan makna dan fungsi kain Ulos dalam opera Batak yang dilakukakan oleh PLOt. Berdasarkan studi literatur dalam menetapkan peta jalan penelitian tampak bahwa penelitian-penelitian terdahulu yang dilakukan terhadap PLOt belum ada yang membahas dari perspektif makna dan fungsi Ulos dalam pertunjukan-pertunjukan Pusat Latihan Opera Batak Pematang Siantar, Sumatera Utara. Dengan demikian, penelitian dari PLOt yang difokuskan kajian pakaian tradisi Ulos Batak merupakan kebaruan dari penelitian ini. Penelitian ini akan menyumbangkan hasil mengenai kajian pakaian tradisi khususnya tentang kain Ulos.

\section{KAJIAN TEORI}

Fungsi menurut kamus lengkap Bahasa Indonesia merupakan kegunaan suatu hal, daya guna serta pekerjaan yang dilakukan. Demikian pun menurut para ahli, yakni, The Liang Gie (dalam Zainal, mengatakan fungsi merupakan sekelompok aktivitas yang tergolong pada jenis yang sama berdasarkan sifatnya, pelaksanaan ataupun pertimbangan lainnya. Definisi tersebut memiliki persepsi yang sama dengan definisi fungsi menurut Sutarto (dalam Zainal 2008:22) mengatakan fungsi adalah rincian tugas yang sejenis atau erat hubungannya satu sama lain untuk dilakukan oleh seorang pegawai tertentu yang masing-masing berdasarkan sekelompok aktivitas sejenis menurut sifat atau pelaksanaannya. Sedangkan pengertian singkat dari definisi fungsi menurut Moekijat (dalam Zainal 2008:22) yaitu fungsi adalah sebagai suatu aspek khusus dari suatu tugas tertentu.

Fungsi merupakan sekelompok aktivitas yang tergolong pada jenis yang sama berdasarkan sifatnya, 
pelaksanaan ataupun pertimbangan lainnya. Definisi tersebut memiliki persepsi yang sama dengan definisi fungsi menurut Sutarto (dalam Zainal 2008:22) mengatakan fungsi adalah rincian tugas yang sejenis atau erat hubungannya satu sama lain untuk dilakukan oleh seorang pegawai tertentu yang masing-masing berdasarkan sekelompok aktivitas sejenis menurut sifat atau pelaksanaannya. Sedangkan pengertian singkat dari definisi fungsi menurut Moekijat (dalam Zainal 2008:22), yaitu fungsi adalah sebagai suatu aspek khusus dari suatu tugas tertentu.

\section{METODE PENELITIAN}

\section{Desain Penelitian}

Penelitian Makna dan Fungsi Ulos pada Pusat Latihan Opera Batak digunakan pendekatan emik berdasarkan analisis deskriptif interpretatif yang mengacu pada proses observasi dan wawancara. Moleong mengatakan, bahwa pendekatan emik merupakan cara yang sahih untuk meneliti bahasa atau satu kebudayaan pada satu waktu tertentu. Pendekatan emik adalah cara berfikir struktural. Peneliti berasumsi, bahwa prilaku manusia terpola dalam sistem pola itu sendiri. Satuansatuan dari sistem terpola tersebut bersama-sama dengan satuan-satuan kelompok struktural itu membentuk masyarakat tertentu melalui aksi dan reaksi anggotanya. (Moleong, 2000: 53-54).

Penelitian ini merupakan penelitian kualitatif deskriptif yang bertujuan untuk mendapatkan suatu gambaran yang menyeluruh dan mendalam mengenai sesuatu pokok bahasan yang ditekankan pada kualitas dan kedalaman makna. Sutopo (2001) menyatakan bahwa penelitian kualitatif memusatkan pada deskripsi. Data yang dikumpulkan terutama berupa kata-kata, kalimat atau gambar yang memiliki arti lebih bermakna dan mampu memacu timbulnya pemahaman yang lebih nyata daripada sekedar sajian angka atau frekuensi. Peneliti menekankan catatan dengan deskripsi kalimat yang rinci, lengkap dan mendalam, yang menggambarkan situasi sebenarnya guna mendukung penyajian data.

Oleh sebab itu penelitian kualitatif secara umum sering disebut sebagai pendekatan kualitatif deskriptif. Jadi dalam mengembangkan pemahaman, penelitian kualitatif cenderung tidak memotong halaman cerita dan data lainnya dengan simbol-simbol angka. Penelitian berusaha menganalisis data dengan semua kekayaan wataknya yang penuh nuansa, sedekat mungkin dengan bentuk aslinya seperti waktu dicatat. (Sutopo, 2006: 40). Senada dengan itu Soedarsono (2001) mengatakan, bahwa dalam penelitian kualitatif
Gorga : Jurnal Seni Rupa

Volume 10 Nomor 01 Januari-Juni 2021

p-ISSN: 2301-5942 | e-ISSN: 2580-2380

seorang peneliti harus mampu mengeksplanasikan semua bagian yang bisa dipercaya dan informasi yang diketahuinya serta tidak akan menimbulkan kontradiksi dengan interpretasi yang disajikan. (Soedarsono, 2001: 201).

Sementara menurut Moleong penelitian kualitatif menggunakan dua metode yaitu kerja lapangan dan laboratorium. Kerja lapangan merupakan proses memilih sumber data yang diperlukan, melakukan wawancara di mana manusia sebagai instrumen utamanya, melakukan perekaman, pencatatan lapangan, dan lain sebagainya. Sementara data yang berhasil dikumpulkan di lapangan, dipilah dan dipilih, dikelompokkan menurut sifat dan jenisnya, dianalisis, dan dieksplanasikan, ini merupakan bagian dari kerja laboratorium.(Moleong, 2000: 111-115).

Sebagai langkah awal pengumpulan data dilakukan dengan mengadakan observasi lapangan. Hal ini menitikberatkan pada pengamatan atau pertunjukan yang didukung dengan wawancara dan perekaman kejadian. Data kualitatif untuk penelitian seni pertunjukan juga dapat didapatkan dari sumber-sumber tertulis, sumber lisan, artefak, peninggalan sejarah serta sumber-sumber rekaman. (Soedarsono, 2001: 192).

\section{Sasaran Penelitian}

Sasaran penelitian ini adalah Pusat Latihan Opera Batak meliputi fungsi dan makna penggunaan kain ulos; sejarah (eksistensi), pendukung (paropera) dan masyarakat pendukung opera batak yang bertempat di Pematang Siantar, Sumatera Utara. Selain itu, juga dilakukan pengumpulan data terhadap group opera batak yang pernah menggunakan kain ulos pada pertunjukan-pertunjukan opera batak.

\section{1). Teknik Pengumpulan Data}

Teknik pengumpulan data yang digunakan pada penelitian ini adalah studi pustaka, studi arsip berita pertunjukan, observasi, dan wawancara.

\section{2). Studi Pustaka}

Studi terhadap kepustakaan dilakukan agar dapat menemukan landasan konseptual yang tidak menyimpang terhadap proses kreatif satu group seni Opera Batak, sekaligus menjadi bahan penyusunan laporan penelitian. Data awal dan data lanjutan dalam penelitian ini diperoleh dari sumber pustaka berupa artikel, buku, majalah dan sebagainya yang mempunyai hubungan, baik secara langsung maupun tidak langsung dengan masalah yang akan diteliti.

Adapun buku-buku yang berhubungan dengan kajian fungsi dari pertunjukan tersebut yakni pada buku 
Gorga : Jurnal Seni Rupa

Volume 10 Nomor 01 Januari-Juni 2021

p-ISSN: 2301-5942 | e-ISSN: 2580-2380

Soedarsono (2001), dalam tulisannya menjelaskan apa fungsi seni pertunjukan di tengah masyarakat, serta bagaimana kedudukan seni pertunjukan (tradisi) di era globalisasi. Buku ini kiranya dapat dijadikan acuan untuk mengetahui berbagai fungsi seni pertunjukan di masyarakat terutama tentang fungsi pola-pembentukan pertunjukan teater rakyat yang bersifat improvisasi.

\section{3). Observasi}

Tehnik pengumpulan data selanjutnya adalah observasi. Observasi dilakukan untuk memperjelas deskripsi dan analisis data-data yang disajikan. Jenis observasi yang dilakukan peneliti adalah observasi berperan penuh, di mana peneliti tidak hanya mengamati tetapi juga dapat bertanya. (Sutopo, 2006: $80)$.

Tujuan observasi adalah mendeskripsikan setting yang dipelajari, aktivitas-aktivitas yang berlangsung, orangorang yang terlibat dalam aktivitas, dan makna kejadian di lihat dari perspektif mereka yang terlibat dalam kejadian yang diamati tersebut.

Observasi yang berhubungan dengan penelitian ini telah penulis lakukan sebelumnya pada tahun 2010 . Pada saat kunjungan ke Pusat Latihan Opera Batak penulis berkesempatan melakukan pendokumentasian berupa foto dan menyaksikan langsung latihan-latihan karena masa itu Pusat latihan Opera Batak sedang mempersiapkan pertunjukan opera batak. Penulis berkesempatan juga menyaksikan bagian penggunaan ulos pada kostum-kostum pertunjukan Opera Batak. Kiranya observasi awal tersebut merupakan modal untuk menemukan kelanjutan pertanyaan-pertanyaan mendasar tentang Pusat Latihan Opera Batak ini. Dalam melakukan observasi ini penulis dibantu dengan alat Kamera foto.

\section{4). Wawancara}

Proses berikutnya dan merupakan langkah terpenting dari pengumpulkan data dalam penelitian ini adalah wawancara. Wawancara dilakukan dengan cara bebas dan mendalam (in-depth interview), yaitu proses memperoleh keterangan dengan cara tanya jawab sambil bertatap muka antara pewawancara dengan informan atau orang yang diwawancarai, dengan atau tanpa menggunakan pedoman (guide) wawancara. Keunggulannya ialah memungkinkan peneliti mendapatkan jumlah data yang banyak, sebaliknya kelemahan ialah karena wawancara melibatkan aspek emosi, maka kerjasama yang baik antara pewawancara dan yang diwawancarai sangat diperlukan (Hariwijaya, 2007: 73-74)
Cara ini memungkinkan pihak yang diwawancarai untuk mendefinisikan dirinya sendiri dan lingkungannya. Peneliti lebih mengharapkan kepada subjek penelitian agar jawabannya tidak hanya sekedar jujur tetapi juga cukup lengkap dan terjabarkan. Wawancara dilakukan dengan wawancara terbuka dan wawancara mendalam, dan terstruktur. Model ini dapat saja berkembang di lapangan menyesuaikan dengan kondisi. Wawancara mendalam dilakukan dengan para pendiri Pusat Latihan Opera Batak dan anggota grup. Wawancara dibantu dengan alat perekam dan dilakukan pencatatan untuk mengetahui pandangan mereka. Dalam melakukan tahap wawancara ini, digunakan pula alat bantu berupa kamera foto untuk pendokumentasian.

Proses selanjutnya, peneliti juga melakukan wawancara kepada orang yang dianggap mampu dalam menjawab permasalahan di dalam penelitian. Nara sumber utama adalah mereka yang sebelumnya merupakan informan pada penelitian yang dituliskan oleh peneliti sebelumnya dan nara sumber lainnya.

\section{5). Analisis Data}

Tahapan akhir dalam penelitian ini adalah mengolah data, yaitu dengan cara menyeleksi dan mengidentifikasi data, mengklasifikasikannya, lalu kemudian dianalisis dan dideskripsikan ke dalam tulisan. Analisis data dilakukan dengan menghubunghubungkan dan membanding-bandingkan setiap data yang telah diseleksi dengan kerangka teori yang digunakan dan disesuaikan dengan tujuan penelitian. Analisis data dilakukan dengan memahami dan menerjemahkan data yang dikumpulkan, untuk selanjutnya mengutarakan hasilnya dalam bentuk uraian. Analisis data dilaksanakan secara bersamaan, sejak pengumpulan data awal sampai pada penulisan tesis berakhir.

Menganalisis data yang terkumpul melalui teknik wawancara, di mana data yang terkumpulkan sumbernya beragam dan belum teruji kebenarannya, digunakan teknik trianggulasi sumber (Sutopo, 2006: 80). Beberapa narasumber wawancara akhirnya dicari kesamaan persepsi mereka sebagai kesimpulan sementara, untuk menjawab rumusan masalah, dalam hal ini dilakukan analisis dengan pendekatan emik untuk mencari benang merahnya. Data wawancara kemudian dibandingkan dengan dengan data tertulis yang didapatkan melalui studi pustaka. Adapun kesimpulan yang didapatkan melalui perbandingan itu, selanjutnya dibandingkan pula dengan data observasi dan data hasil arsip dari berbagai aktifitas Pusat Latihan Opera Batak, untuk melihat korelasi antara pengunaan 


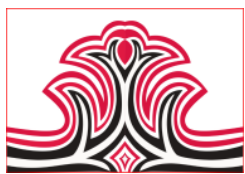

kain ulos pada acara adat dan penggunaan kain ulos pada pertunjukan opera Batak.

Berdasarkan tekhnik analisis data tersebut, penelitian ini menyajikan tentang nilai-nilai pada kain ulos, makna dan fungsi pada upacara-upacara adat maupun pada pertunjukan-pertunjukan opera Batak group Pusat Latihan Opera Batak. Penelitian ini juga sebagai kepedulian bidang kajian pusat pakaian tradisi yang memiliki tanggungjawab dalam mengarsipkan dan serta mendokumentasikan pakaian tradisi khususnya ulos terkait makna dan fungsinya.

\section{HASIL DAN PEMBAHASAN}

\section{Hasil}

Berdasarkan hasil pengamatan langsung serta wawancara yang dilakukan sebagai bagian dari penelitian ini, maka dapat dilihat bahwa, penggunaan Ulos pada PLOt Pematang Siantar didasari atas kebutuhan peran dalam pemanggungan pertunjukan opera Batak. Praopera pada PLOt cukup signifikan dalam mempertahankan penggunan ulos hasil tenunan tangan Hal ini dilakukan untuk kelangsungan penenun ulos.

\section{Pembahasan}

Penelitian "Makna dan Fungsi kain Ulos pada PLOt Pematang Siantar Provinsi Sumatera Utara" merupakan penelitian kualitatif deskriptif yang bertujuan untuk mendapatkan suatu gambaran yang menyeluruh dan mendalam mengenai makna dan fungsi kain Ulos pada PLOt Pematang Siantar provinsi Sumatera Utara yang ditekankan pada kualitas dan kedalaman makna Sutopo (2006) menyatakan bahwa penelitian kualitatif memusatkan pada deskripsi. Data yang dikumpulkan terutama berupa kata-kata, kalimat atau gambar yang memiliki arti lebih bermakna dan mampu memacu timbulnya pemahaman yang lebih nyata daripada sekedar sajian angka atau frekuensi. Peneliti menekankan catatan dengan deskripsi kalimat yang rinci, lengkap dan mendalam, yang menggambarkan situasi sebenarnya guna mendukung penyajian data. Soedarsono (2001: 201) mengatakan, bahwa dalam penelitian kualitatif seorang peneliti harus mampu mengeksplanasikan semua bagian yang bisa dipercaya dan informasi yang diketahuinya serta tidak akan menimbulkan kontradiksi dengan interpretasi yang disajikan.

Penelitian ini juga menggunakan pendekatan emik berdasarkan analisis deskriptif interpretatif yang mengacu pada proses observasi dan wawancara. Moleong (2000: 53-54) mengatakan, bahwa pendekatan emik merupakan cara yang sahih untuk
Gorga : Jurnal Seni Rupa

Volume 10 Nomor 01 Januari-Juni 2021

p-ISSN: 2301-5942 | e-ISSN: 2580-2380

meneliti bahasa atau satu kebudayaan pada satu waktu tertentu. Pendekatan emik adalah cara berfikir struktural.

Pada masyarakat Batak kain tradisional dikenal dengan sebutan Ulos. Ulos terbuat dari tenunan ikat yang dibuat secara tradisional. Sampai saat ini Ulos sebagai kain tradisional Batak Toba yang dikenali oleh masyarakat luas oleh karena corak dan motifnya. Berdasarkan fungsinya, Ulos dibedakan menjadi dua yakni, untuk kegiatan sehari-hari dan untuk pelaksanaan upacara adat. Pada laki-laki bagian atasnya disebut bande-bande, yang di bawah disebut singkot dan penutup kepala disebut tali-tali. Sedangkan pada perempuan bagian bawah hingga batas dada disebut baen, penutup punggung disebut boba-boba, dan bila digunakan sebagai selendang disebut ampeampe dan sebagai penutup kepala disebut soong.

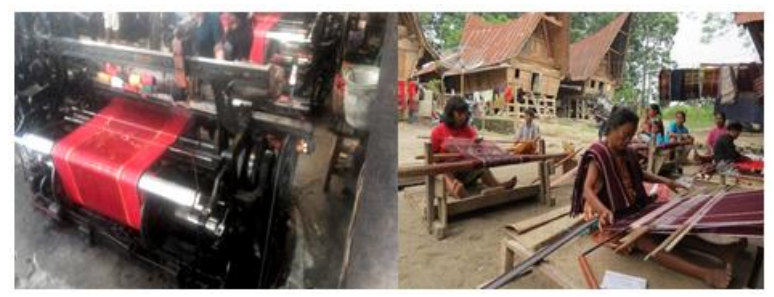

Gambar 1. Kiri, Mesin penenun Ulos di Balige (Alamo, 2020) dan Kanan, Ulos Tenunan Tangan (Heta News. 2020)

Makna dan fungsi Ulos masing-masing daerah (Toba, Angkola, Pakpak, Dairi, Karo) pada hakekatnya sama, perbedaan terlihat pada motif dan penamaan kain Ulos.

Kekayaan motif-motif (ragi) kain Ulos merupakan warisan yang harus dijaga, secara adat fungsi dan makna Ulos di masyarakat Batak pada dasarnya sama yang membedakan hanyalah 'ekspresi marga', misalnya, pada lingkaran marga Silalahi ada 4 jenis Ulos yang tidak bisa digunakan secara sembarang di luar lingkaran marga Silalahi. Keempat Ulos itu adalah gobar (Ulos patris Silalahi), simangkatangkat (Ulos menantu perempuan Silalahi), polang-polang (Ulos menantu pria Silalahi), ragi siantar (Ulos Boru Silalahi yang belum menikah). 


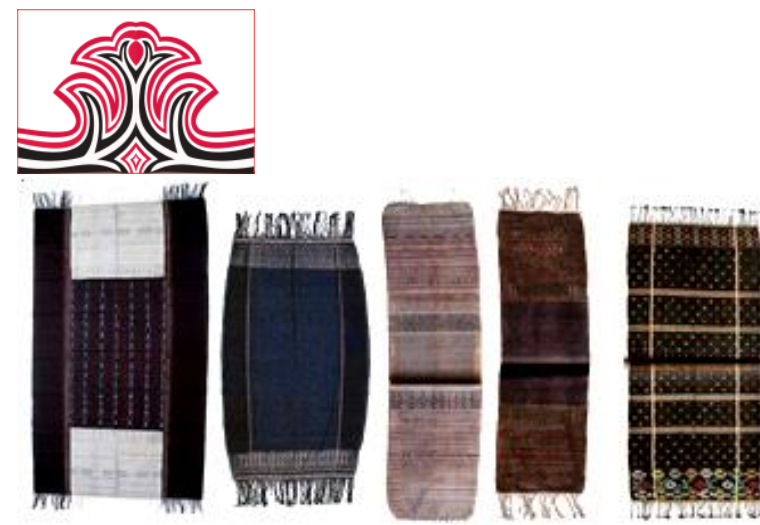

Gambar 2. Ulos Ragidup, Ragi Hotang, Tumtuman, Sadum Tarutung (Emir. Threes dan Wattimena. Samuel, 2017. Pesona Kain Indonesa, Kain Ulos Danau Toba. Jakarta: Kompas Gramedia)

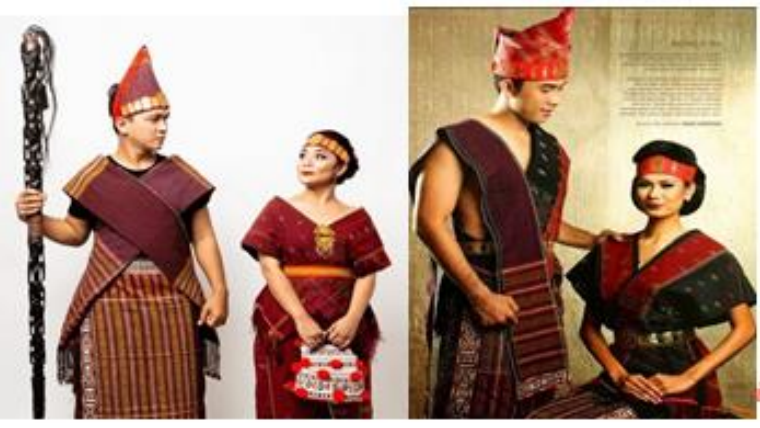

Gambar 3. Penggunaan Ulos dalam Masyarakata Batak Toba (Dinas Pariwisata Provinsi Sumatera Utara)

Fungsi Ulos pada PLOt Pematang Siantar. Sumatera Utara, selain sebagai kostum pendukung pertunjukan opera Batak, Ulos juga merupakan identitas kelompok. Dalam hal ini, PLOt Pematang Siantar membiasakan diri menggunakan Ulos-Ulos hasil tenunan tangan, baik pada proses latihan maupun dalam kehidupan seharihari (syal, ikat kepala, dililitkan dibadan). Hal ini sebagai satu upaya pemberdayaan para perajin Ulos agar memiliki pasar yang signifikan. Pada setiap kesempatan; talkshow, seminar, workshop bahkan sesudah pertunjukan group opera Batak berlangsung, disampaikan tentang penggunaan Ulos pada para penonton. Hal ini salahsatu bagian dari proses meedukasi masyarakat yang masih menganggap tabu memakai Ulos dalam kehidupan sehari-hari.

Dampak dari pemakaian Ulos dalam kehidupan seharihari secara ekonomi tentunya akan menguntungkan perekonomian masyarakat penenun Ulos; meningkatnya pesanan Ulos tenunan tangan, dan menumbuhkan generasi penenun Ulos yang baru. Masyarakat Batak pada umumnya memiliki citarasa dalam mengkoleksi kain Ulos. Mereka lebih bangga menyimpan Ulos tenunan tangan dibanding Ulos olahan mesin tenun.

Materi edukasi yang diberikan pada masyarakat antara lain: tentang tingkatan, makna dan fungsi Ulos sehingga penggunaan Ulos tidak menyalahi nilai-nilai yang terkandung dan aturan yang ada. Hal ini secara
Gorga : Jurnal Seni Rupa

Volume 10 Nomor 01 Januari-Juni 2021

p-ISSN: 2301-5942 | e-ISSN: 2580-2380

prinsif tidak jauh berbeda dengan penggunaan dan pembagian Ulos dalam adat Batak. Ada Ulos yang bisa dipakai laki-laki (biasanya, Ragi Hotang) dan ada Ulos yang hanya boleh digunakan perempuan (biasanya, Bintang Maratur). Penggunaan Ulos dalam Pusat Latihan Opera Batak Pematang Siantar di pilih berdasarkan kategori peran/tokoh yang ada dalam cerita opera Batak.
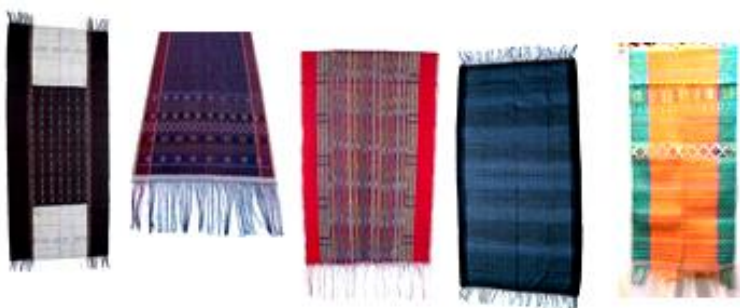

Gambar 4. Ulos Ragidup, Ragi Hotang, Mangiring, Sibolang, Sadum Tarutung (PLOt, 2020)

Pengunaan Ulos pada PLOt memiliki pengaruh yang kuat karena selain sebagai identitas kelompok, kain Ulos juga sebagai sarana pendukung kostum pertunjukan yang dapat mengekspresikan karakter dari pertunjukan yang mereka usung. Selain sarana pendukung pertunjukan Ulos yang dapat digunakan sebagai busana, selendang, selimut, dan kain gendongan. (Tambunan. 1977:186). Ulos digunakan oleh masyarakat Batak untuk memenuhi kebutuhan sehari-hari dan kebutuhan adat tradisi. (Basyral dan Hotman.1987: 21).

Pilihan Ulos yang sering digunakan dalam pertunjukan PLOt adalah: Ulos Ragi hotang (Ulos corak rotan) mengandung arti kekuatan dan keuletan. Ulos Ragidup (corak hidup), Ulos ini sarat dengan 'nilai' kehidupan dan bisa juga kita temui dalam adat pesta perkawinan.

Penggunaan kain Ulos pada PLOt Pematang Siantar tidak saja karena pertimbangan estetika pertunjukan namun juga pertimbangan kepatutan kain Ulos yang digunakan. Hal ini tercermin dari sikap sehari-hari paropera yang tergabung di Pusat Latihan Opera Batak. Mereka selalu membawa kain Ulos yang disesuaikan dengan kegiatan kebudayaan seperti: workshop, talkshow, seminar. Ulos menjadi satu ciri kostum atau bagian dari pertunjukan Opera Batak.

Demikian, halnya saat PLOt melakukan pertunjukan. Maknanya bisa berbeda dari dulu dan sekarang. Awalnya di PLOt, makna dan fungsinya tidak diketahui semua pemain. Sehingga harus dipandu, Ulos yang berfungsi untuk pria dan perempuan. Setiap Ulos memiliki makna yang berbeda dan tergantung si pemberi dan si penerima. Sehingga di pertunjukan 


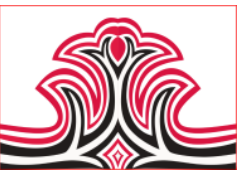

Opera Batak ada kalanya setiap pemain membawa Ulos dari rumahnya. Sedangkan yang tidak membawa terpaksa menggunakan Ulos apa adanya; atau yang umum seperti Ragihotang dan Sadum. Dulu setiap orang memiliki minimal dua Ulos; untuk keseharian dan menghangatkan. Jika di tingkat adat, ritual, dan upacara penggunaan atau pemakaian jenis-jenis Ulos tertentu terkait dengan status atau posisi sosialnya. Imaji untuk itu dalam setiap pertunjukan PLOt diusahakan ketersediaannya, apalagi dengan Ulos yang tidak dikenal baik lagi fungsinya. Makna Ulos dalam pertunjukan bisa mewakili kemegahan dan pengetahuan tentang masa lalu. (wawancara, Tompson Parningotan Hutasoit 21 Agustus 2020).
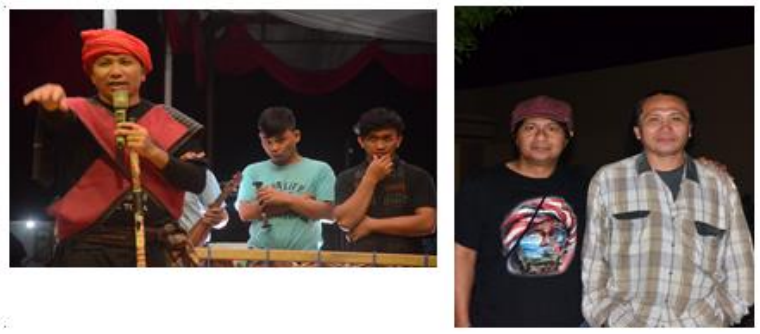

Gambar 5. Tompson Parningotan Hutasoit pendiri Pusat Latihan Opera Batak Pematang Siantar dan peneliti dalam Iven Batak Fest di Balige (PLOt, 2018)

Cara-cara pembagian dan penggunaan Ulos terhadap praopera pun sangat diperhatikan. Hal ini menimbulkan kesan yang mendalam. Sehingga para pemain lama yang pernah bergabung di PLOt selalu tidak lupa bawa Ulosnya setiap ada pertunjukan. Malahan juga menyandingkannya sebagai bagian dari keseharian. Ada Ulos tertentu yang bisa digunakan untuk keseharian, seperti Ulos Bintang Maratur (feminim) dan Ulos mangiring (maskulin). Hal ini berbeda dengan pemain-pemain yang baru yang acapkali bingung kalau disuruh bawa Ulos sendiri dari rumah. Kadang ada yang membawa, tapi salah. Perempuan bawa Ulos ragihotang (maskulin), pria bawa Ulos sadum (feminim). Di situ kesalahannya. Dari kesalahan itu akhirnya ada pembelajaran atau informasi tentang Ulos dan penggunaannya (cara memakai dan kelazimannya). (wawancara, Tompson Parningotan Hutasoit 21 Agustus 2020).

Penggunaan Ulos untuk pemain perempuan dan Ulos untuk pemain laki-laki antara yang keseharian, untuk adat, ritual, dan upacara ada jenis Ulos tertentu bagi pria (maskulin) dan perempuan (feminim). Tapi untuk ikat kepala terkadang digunakan yang keseharian itu tanpa membedakan peruntukannya lagi. Yang penting disiasati motifnya agar tidak menonjol waktu diikatkan, dan malahan memberikan nuansa baru. Ulos keseharian dan di adat yang biasa diikatkan adalah mangiring. Tapi
Gorga : Jurnal Seni Rupa

Volume 10 Nomor 01 Januari-Juni 2021

p-ISSN: 2301-5942 | e-ISSN: 2580-2380

bisa juga digunakan sebagai kain untuk menggendong bayi sebagaimana juga dengan Ulos Bintang Maratur. (wawancara, Tompson Parningotan Hutasoit 21 Agustus 2020).

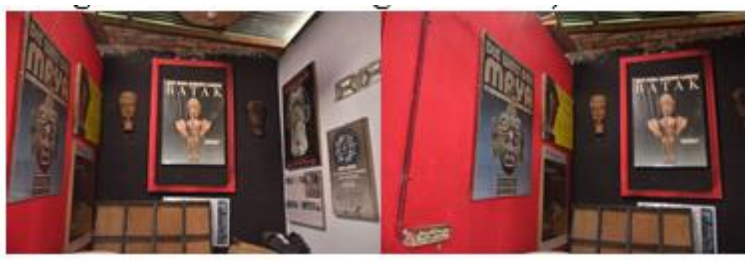

Gambar 6. Sekretariat PLOt Pematang Siantar (Alamo, 2018)

Pandangan terhadap penggunaan Ulos masa kini Tompson mengulas, penggunaan Ulos secara umum tidak dipraktikkan lagi sesuai peruntukannya karena sempat ada stigma negatif terhadap Ulos dan penggunaannya. Ulos dengan suatu kebanggaan tertentu digunakan sebagai bagian dari mode, meskipun masih banyak kelompok ritual dan upacara-upacara yang masih mempertahankan cara penggunaannya. (wawancara, Tompson Parningotan Hutasoit 21 Agustus 2020).

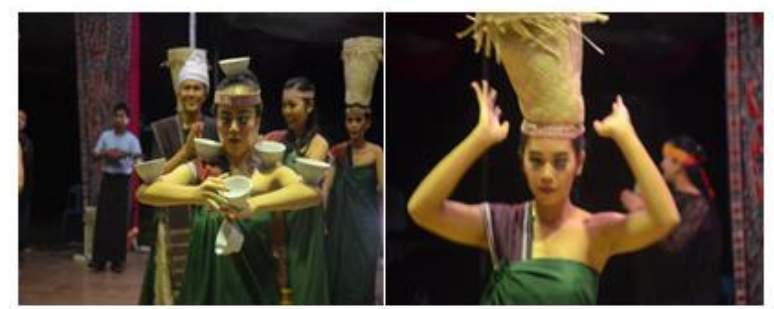

Gambar 7. Pertunjukan PLOt memakai Ulos dalam Iven Batak Fest di Balige tahun 2018 (Alamo, 2018)

Selain mewancarai Tompson Parningotan Hutasoit pada hari sebelumnya tanggal, 15 Agustus 2020 secara terpisah di desa dengan ketinggian $1400 \mathrm{~m}$ diatas permukaan laut Geopark Sipinsor Tapanuli Utara peneliti mewancarai Oktavianus yang merupakan anggota dari Pusat Latihan Opera Batak. Oktavianus juga pendiri Komunitas Sitopak Sada. Oktavianus menjelaskan, penggunaan Ulos tidak saja dalam pertunjukan-pertunjukan Pusat Latihan Opera Batak tapi juga dalam acara talk show dan workshop. Pemakaian Ulos ini dalam rangka meredukasi masyarakat bahwasanya Ulos bukan sebagai kain yang digunakan dalam acara adat saja tetapi juga tidak bisa digunakan dalam kegiatan sehari-hari hanya saja pilihan Ulosnya yang disesuaikan mana yang dapat dipergunakan untuk keseharian dan mana yang khusus untuk acara budaya. 

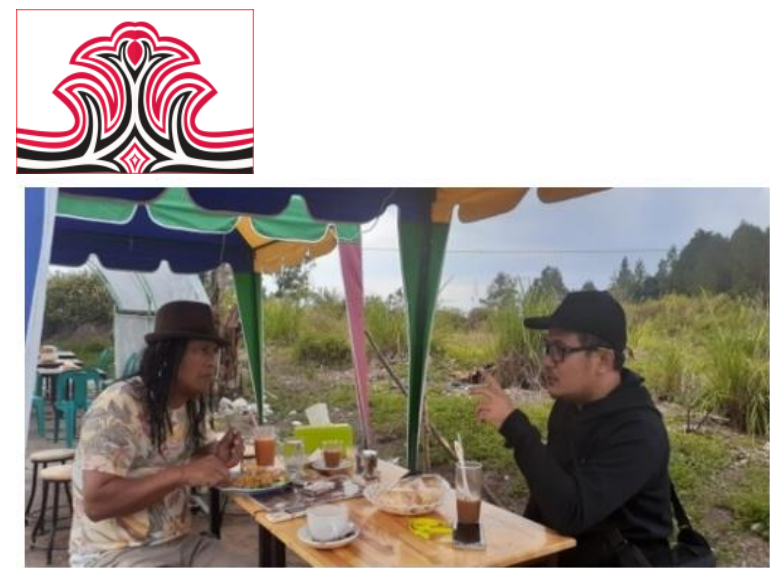

Gambar 8. Peneliti mewawancarai Oktavianus Matondang (anggota PLOt) di desa Geopark Sipinsor Tapanuli Utara (Alamo, 2020)

Ulos jika hanya digunakan pada acara adat saja menyebabkan minimnya pesanan pada perajin tenun Ulos. Dalam menghidupkan perajin masyarakat dimotivasi untuk memakai Ulos sehari-hari agar perekenomian menjadi maju. Hal ini senada dengan yang disampaikan Tompson Parningotan Hutasoit. Lebih lanjut, Oktavianus menyampaikan tidak semua Ulos digunakan oleh Pusat Latihan Opera Batak dalam proses latihan, talkshow dan workshop mereka harus memilih Ulos sesuai dengan kepatutan dan kepantasan yang telah digariskan dalam nilai-nilai adat dan tingkatan Ulos itu sendiri.

Tabel 1.

Tabulasi Ulos Lingkaran Batak Toba (Bakkara, Balige, Silalahi, Paropo, Tongging, Meat, Samosir, Lumban Suhisushi, Toba Holbung/Uluan, Muara dan Tarutung)

\begin{tabular}{|c|c|c|c|}
\hline No & Nama & Fungsi & Fungsi dalam Adat \\
\hline 1 & Ragidup & $\begin{array}{l}\text { digunakan oleh } \\
\text { orang tua, laki- } \\
\text { laki maupun } \\
\text { perempuan }\end{array}$ & $\begin{array}{l}\text { merupakan ulos } \\
\text { dalam upacara } \\
\text { adat berdasarkan } \\
\text { status }\end{array}$ \\
\hline 2 & $\begin{array}{l}\text { Ragi } \\
\text { Hotang }\end{array}$ & $\begin{array}{l}\text { diberikan kepada } \\
\text { sepasang } \\
\text { pengantin yang } \\
\text { sedang } \\
\text { melaksanakan } \\
\text { pesta adat (Ulos } \\
\text { Hela) }\end{array}$ & $\begin{array}{l}\text { Ulos diberikan } \\
\text { untuk sebagai } \\
\text { mempererat } \\
\text { hubungan } \\
\text { sepasang } \\
\text { pengantin di } \\
\text { sertai mandar } \\
\text { Hela (sarung } \\
\text { menantu) yang } \\
\text { menunjukkan } \\
\text { laki-laki tersebut } \\
\text { sudah dipersunting. } \\
\text { Sarung dibawa } \\
\text { untuk kegiatan } \\
\text { adat }\end{array}$ \\
\hline 3 & Tumtuman & $\begin{array}{lr}\text { Ulos ini } & \text { dipakai } \\
\text { oleh } & \text { anak } \\
\text { pertama } & \text { sebagai } \\
\text { tali-tali } & \text { yang } \\
\text { bermotif. } & \end{array}$ & $\begin{array}{l}\text { Penanda bahwa } \\
\text { yang } \\
\text { bersangkutan } \\
\text { adalah anak } \\
\text { pertama dari } \\
\text { hasuhutan (tuan } \\
\text { rumah) }\end{array}$ \\
\hline
\end{tabular}

Gorga : Jurnal Seni Rupa

Volume 10 Nomor 01 Januari-Juni 2021

p-ISSN: 2301-5942 | e-ISSN: 2580-2380

\begin{tabular}{|c|c|c|c|}
\hline 4 & $\begin{array}{l}\text { Sadum } \\
\text { Tarutung }\end{array}$ & $\begin{array}{l}\text { penggunaannya } \\
\text { pada pertunjukan } \\
\text { karena Ulos ini } \\
\text { juga dapat } \\
\text { digunakan sebagai } \\
\text { ikat kepala dengan } \\
\text { teknik manipulasi } \\
\text { penggulungan } \\
\text { untuk mengaburkan } \\
\text { motifnya }\end{array}$ & $\begin{array}{l}\text { penggunaannya } \\
\text { dalam adat bisa } \\
\text { sebagai ikat kepala }\end{array}$ \\
\hline 5 & Ragi Huting & $\begin{array}{l}\text { biasanya dipakai } \\
\text { sebagai penutup } \\
\text { punggung } \\
\text { perempuan, } \\
\text { sebagai } \\
\text { selendang atau } \\
\text { dililitkan didada } \\
\text { (kemben) sering } \\
\text { dibawa dalam } \\
\text { bepergian. }\end{array}$ & $\begin{array}{l}\text { Ulos ini dipakai } \\
\text { oleh anak } \\
\text { perempuan } \\
\text { sebagai pakaian } \\
\text { sehari-hari yang } \\
\text { dililitkan didada } \\
\text { (hoba-hoba) } \\
\text { sebagai tanda } \\
\text { masih perawan } \\
\text { dan beradat }\end{array}$ \\
\hline 6 & Harungguan & $\begin{array}{l}\text { Ulos harungguan } \\
\text { berarti marunggu } \\
\text { (berkumpul) } \\
\text { karena } \\
\text { banyaknya motif } \\
\text { yang berkumpul } \\
\text { dalam kain Ulos } \\
\text { ini }\end{array}$ & $\begin{array}{l}\text { Ulos ini } \\
\text { digunakan pada } \\
\text { acara sukacita } \\
\text { dan dukacita, } \\
\text { seperti meminta } \\
\text { doa restu untuk } \\
\text { kesuksesan }\end{array}$ \\
\hline 7 & Sibolang & $\begin{array}{l}\text { Ulos yang } \\
\text { digunakan } \\
\text { sebagai } \\
\text { pakaian } \\
\text { sehari-hari } \\
\text { (pada zaman } \\
\text { dulu) yang } \\
\text { kemudian } \\
\text { direduksi } \\
\text { maknanya } \\
\text { (pada zaman } \\
\text { sekarang) } \\
\text { sebagai Ulos } \\
\text { mistis dan } \\
\text { berbau duka }\end{array}$ & $\begin{array}{l}\text { Digunakan di } \\
\text { luar dan di } \\
\text { dalam rumah } \\
\text { tanpa terikat } \\
\text { dengan adat } \\
\text { atau upacara }\end{array}$ \\
\hline 8 & $\begin{array}{l}\text { Harungguan } \\
\text { Lobu-lobu }\end{array}$ & $\begin{array}{l}\text { Ulos ini biasanya } \\
\text { digunakan } \\
\text { sebagai kain } \\
\text { gendongan }\end{array}$ & $\begin{array}{l}\text { Ulos ini } \\
\text { digunakan } \\
\text { sebagai kain } \\
\text { parompa }\end{array}$ \\
\hline 9 & $\begin{array}{l}\text { Bintang } \\
\text { Maratur }\end{array}$ & $\begin{array}{l}\text { bisa untuk } \\
\text { penutup badan } \\
\text { yang berfungsi } \\
\text { sebagai penutup } \\
\text { tubuh } \\
\text { perempuan } \\
\text { sampai sebatas } \\
\text { dada (abit } \\
\text { ginjang) }\end{array}$ & $\begin{array}{l}\text { Pada Batak Toba } \\
\text { ulos ini diberikan } \\
\text { saat acara } \\
\text { selamatan hamil } \\
7 \text { bulan, } \\
\text { diberikan oleh } \\
\text { pihak hula-hula } \\
\text { kepada anaknya }\end{array}$ \\
\hline 10 & Antakantak & $\begin{array}{l}\text { Ulos ini } \\
\text { digunakan sebagai } \\
\text { selendang para } \\
\text { orang tua dalam } \\
\text { melayat keluarga } \\
\text { yang meninggal }\end{array}$ & $\begin{array}{l}\text { dipakai sebagai } \\
\text { kain yang dililit } \\
\text { pada waktu acara } \\
\text { manortor (menari) } \\
\text { dalam helaran } \\
\text { budaya Batak }\end{array}$ \\
\hline 11 & Mangiring & $\begin{array}{l}\text { Ulos ini dipakai } \\
\text { sebagai } \\
\text { selendang, tali- } \\
\text { tali, juga }\end{array}$ & $\begin{array}{l}\text { Ulos ini juga } \\
\text { dapat } \\
\text { dipergunakan } \\
\text { sebagai Parompa }\end{array}$ \\
\hline
\end{tabular}




\begin{tabular}{|c|c|c|c|}
\hline & & $\begin{array}{l}\text { diberikan kepada } \\
\text { anak cucu yang } \\
\text { baru lahir } \\
\text { terutama anak } \\
\text { pertama }\end{array}$ & $\begin{array}{l}\text { (alat gendong) } \\
\text { untuk anak }\end{array}$ \\
\hline 12 & Sitolutuho & $\begin{array}{l}\text { Ulos ini di } \\
\text { fungsikan atau di } \\
\text { pakai sebagai ikat } \\
\text { kepala atau } \\
\text { selendang. }\end{array}$ & \\
\hline 13 & $\begin{array}{l}\text { Marinjam } \\
\text { Sisi }\end{array}$ & $\begin{array}{l}\text { Ulos ini } \\
\text { difungsikan } \\
\text { sebagai kain yang } \\
\text { dilengkapi dengan } \\
\text { Ulos Pinunca } \\
\text { yang di sandang } \\
\text { ditambah } \\
\text { perlengkapan adat } \\
\text { Batak laiinnya } \\
\text { sebagai } \\
\text { Panjoloani } \\
\text { (mendahului di } \\
\text { depan) } \\
\end{array}$ & $\begin{array}{l}\text { Ulos ini } \\
\text { difungsikan } \\
\text { sebagai kain yang } \\
\text { dilengkapi dengan } \\
\text { Ulos Pinunca yang } \\
\text { di sandang } \\
\text { ditambah } \\
\text { perlengkapan adat } \\
\text { Batak laiinnya } \\
\text { sebagai Panjoloani } \\
\text { (mendahului di } \\
\text { depan) }\end{array}$ \\
\hline 14 & $\begin{array}{l}\text { Pinarlobu- } \\
\text { lobuan }\end{array}$ & $\begin{array}{l}\text { Ulos ini biasanya } \\
\text { dipakai oleh } \\
\text { keluarga pihak } \\
\text { kedua yang } \\
\text { melaksanakan } \\
\text { upacara adat } \\
\text { (kakak atau adik) }\end{array}$ & $\begin{array}{l}\text { Ulos ini } \\
\text { digunakan sebagai } \\
\text { kain } \\
\text { hohop(penutup } \\
\text { tubuh bagian atas) } \\
\text { untuk laki-laki dan } \\
\text { perempuan } \\
\text { sebagai tuan } \\
\text { rumah dalam } \\
\text { pelaksanaan } \\
\text { upacara adat. }\end{array}$ \\
\hline 15 & Sumbat & $\begin{array}{l}\text { Ulos ini } \\
\text { digunakan sebagai } \\
\text { selendang oleh } \\
\text { orang yang } \\
\text { dituakan pada saat } \\
\text { upacara besar }\end{array}$ & $\begin{array}{l}\text { Ulos ini } \\
\text { digunakan sebagai } \\
\text { selendang oleh } \\
\text { orang yang } \\
\text { dituakan pada saat } \\
\text { upacara besar }\end{array}$ \\
\hline 16 & Sirara & $\begin{array}{l}\text { Ulos ini dominan } \\
\text { menggunakan } \\
\text { warna merah } \\
\text { dengan motif } \\
\text { yang cerah. }\end{array}$ & $\begin{array}{l}\text { Dipakai biasanya } \\
\text { untuk acara-acara } \\
\text { baik pernikahan } \\
\text { maupun undangan } \\
\text { sukacita lainnya }\end{array}$ \\
\hline 17 & Pinunsaan & $\begin{array}{l}\text { Ulos ini terdiri } \\
\text { dari lima bagian } \\
\text { yang ditenun } \\
\text { secara terpisah } \\
\text { kemudian } \\
\text { disatukan hingga } \\
\text { menjadi satu Ulos }\end{array}$ & $\begin{array}{l}\text { Ulos ini } \\
\text { digunakan oleh } \\
\text { tuan rumah atau } \\
\text { pelaksaan upacara } \\
\text { adat sebagai baju } \\
\text { keluarga tuan } \\
\text { rumah dalam } \\
\text { upacara } \\
\text { marpaniaran }\end{array}$ \\
\hline 18 & $\begin{array}{l}\text { Simarhapis } \\
\text { oran }\end{array}$ & $\begin{array}{l}\text { Ulos ini termasuk } \\
\text { jenis Ulos yang } \\
\text { langka, bahkan } \\
\text { banyak yang tidak } \\
\text { tahu dengan Ulos } \\
\text { ini. }\end{array}$ & $\begin{array}{l}\text { Ulos ini berfungsi } \\
\text { sebagai selendang } \\
\text { perempuan Batak }\end{array}$ \\
\hline 19 & Lobu-lobu & $\begin{array}{l}\text { Merupakan Ulos } \\
\text { yang eksentrik. } \\
\text { Kedua ujungnya } \\
\text { bersatu } \\
\text { sebagaimana } \\
\text { layaknya kain } \\
\text { sarung dan } \\
\text { dipakai oleh } \\
\text { perempuan }\end{array}$ & $\begin{array}{l}\text { Jenis ini juga } \\
\text { sering dijadikan } \\
\text { parompa } \\
\text { Dinamakan Lobu- } \\
\text { lobu agar semua } \\
\text { kebaikan marlobu } \\
\text { (masuk kerumah } \\
\text { yang } \\
\text { memakainya) }\end{array}$ \\
\hline
\end{tabular}

Gorga : Jurnal Seni Rupa

Volume 10 Nomor 01 Januari-Juni 2021

p-ISSN: 2301-5942 | e-ISSN: 2580-2380

\section{KESIMPULAN DAN SARAN}

\section{Kesimpulan}

Penggunaan kain Ulos pada group opera Batak, Pusat Latihan Opera Batak (PLOt) Pematang Siantar tidak terlepas dari kebutuhan kostum pendukung pertunjukan opera Batak yang mereka usung. Walaupun masingmasing pertunjukan memiliki estetika dan kebutuhan cerita tidak serta merta penggunaan Ulos menjadi abai. Hal ini menjadi perhatian, khususnya bagi group opera Batak yang sudah malang melintang untuk mempertahankan dalam melestarikan kesenian opera Batak ini. Mereka membaginya sesuai dengan makna dan fungsi setiap Ulos. Bahkan lebih spesifik group ini telah memilah-milah Ulos yang bisa digunakan lakilaki dan sebaliknya, Ulos yang boleh digunakan oleh pemain perempuan baik untuk keseharian maupun dalam pertunjukan. Karena Ulos memiliki makna dan fungsi yang berbeda-beda. Pusat Latihan Opera Batak Pematang Siantar tidak saja konsen dalam menggarap cerita-cerita opera Batak hingga sekarang, namun lebih jauh group ini beberapa kali melakukan pelatihanpelatihan opera Batak pada generasi muda. Pompa kreativitas ini terus mereka hembuskan bagi keberlangsungan opera Batak dalam seni pertunjukan di Indonesia.

Pusat Latihan Opera Batak Pematang Siantar juga banyak bekerjasama dengan pemerintah daerah dan unsur terkait dalam menumbuhkembangkan serta melestarikan opera Batak. Lebih jauh misi dari group ini adalah memasyarakatkan penggunaan atau pemakain Ulos, selama ini terbatas pada acara adat; Ulos lebih sering digunakan hanya pada acara pernikahan dan kematian. Padahal Ulos bisa dipakai dalam kegiatan sehari-hari. Jika ini dilakukan oleh setiap masyarakat Batak tentunya dapat meningkatkan produktivitas kain Ulos. Tidak menutup kemungkinan hal ini berpengaruh pada kehidupan petenun tangan (tradisional). Masyarakat Batak memiliki 'gengsi' tersendiri jika menggunakan Ulos hasil tenunan tangan dibandingkan tenun yang diproduksi oleh mesin tenun.

\section{Saran}

Minimnya pendanaan mengakibatkan kendala penelitian dilapangan. Hal ini membuat peneliti berjibaku untuk mengupayakan selesainya penelitian ini. Tentunya, pencapaian penelitian belum sesuai harapan. Ada beberapa saran yang perlu dipertimbangkan bagi lembaga terkait, terutama percepatan dana penelitian agar keluar tepat waktu. Mensegerakan kajian-kajian mengenai pakaian tradisi yang tidak terbatas wilayahnya. Hal ini perlu didorong agar lembaga seni menjadi satu tujuan pustaka terutama mengenai pakaian-pakaian tradisi di Sumatera. Bagi 


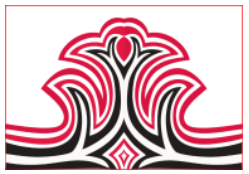

dinas terkait, perlu memberi ruang agar perekonomian penenun tradisi menjadi lebih baik semisal, wajib membeli kain ulos hasil tenunan tangan.Memberi bantuan peralatan tenun dan mempromsikan pentingnya penggunaan ulos hasil tenunan tangan.

\section{DAFTAR RUJUKAN}

Alamo, E., Minawati, R., Sulaiman, S., \& Novalinda, S. (2020). Opera Batak Sisingamangaraja XII Episode Ugamo Malim Horja Bolon $\mathrm{Na}$ Parpudi: Usungan Tradisi dan Kontemporer. Dance and Theatre Review: Jurnal Tari, Teater, dan Wayang, 3(2), 59.

Emir. Threes dan Wattimena. Samuel. (2017). Pesona Kain Indonesa, Kain Ulos Danau Toba. Jakarta: Kompas Gramedia.

Hariwijaya, M. (2007). Metodologi dan Tehnik Penulisan Skripsi, Tesis, dan Disertasi. : Elmatera Publishing.

Harahap, B.H. dan H.M. Siahaan. (1987). Orientasi Nilai-Nilai Budaya Batak. Jakarta: Sanggar Willem Iskandar.

Hasibuan, Jamaludin. (1985). Art Et Culture: Seni Budaya Batak. Jakarta: PT Jayakarta Agung Offset.

Moleong, Lexy J. (2000). Metodologi Penelitian Kualitatif. Bandung: Remaja Rosdakarya.

Niessen, SA. (1985). Motifs of Life in Toba Batak Texts and Textiles. Belanda: Foris Publications.

Oktavianus, Matondang. (2020). “Opera Batak Pematang Siantar (Plot)". Hasil Wawancara Pribadi: 15 Agustus 2020, Pematang Siantar.

Situmorang, Sitor. (2004). Toba Na Sae. Jakarta: Komunitas Bambu.

Soedarsono, R.M. (2001). Metodologi Seni Pertunjukan Dan Seni Rupa, Bandung: Masyarakat Seni Pertunjukan Indonesia.

Sutopo, H.B. (2006). Metodologi Penelitian Kualitatif Dasar Teori dan Terapannya dalam Penelitian. Surakarta: UNS Press.

Soemardjo, Jakob dan Saini. (1997). Apresiasi Kesusasteraan. Jakarta: Gramedia Pustaka Utama.

Tompson Parningotan Hutasoit. (2020). "Opera Batak Pematang Siantar (Plot)". Hasil Wawancara Pribadi: 21 Agustus 2020, Pematang Siantar.

Vergouwen, J.C. (1986). Masyarakat dan Hukum Adat Batak Toba (terjemahan).Jakarta: Pustaka Azet.

Zainal, N. H. (2008). Analisis Kesesuaian Tugas Pokok Dan Fungsi Dengan Kompetensi Pegawai Pada Sekretariat Pemerintah Kota Makasar. Makassar: Fisipol. 